\title{
Materijalno blagostanje kao objektivna dimenzija kvalitete života stanovništva ruralnih prostora - općina Gornja Rijeka
}

\section{Sanja Klempić Bogadi}

Institut za migracije i narodnosti, Zagreb, Hrvatska

e-mail:sanja.klempic@imin.hr

\section{Sonja Podgorelec}

Institut za migracije i narodnosti, Zagreb, Hrvatska

e-mail:sonja.podgorelec@imin.hr

\author{
Monika Šabijan \\ Dropkovec, Hrvatska \\ e-mail:monika.sabijan@gmail.com
}

\begin{abstract}
SAŽETAK U radu se analizira drugi ${ }^{1}$ dio rezultata empirijskog istraživanja provedenog u naseljima općine Gornja Rijeka, čiji je cilj bio proširiti spoznaje o uvjetima koji određuju kvalitetu života stanovništva ruralnih područja Hrvatske. Prema definiciji Cumminsa (1997.), materijalno blagostanje jedan je od temeljnih kompozitnih pokazatelja ukupne kvalitete života. Za potrebe ovoga rada mjereno je pitanjima o kvaliteti stanovanja, opremljenosti stanova elementarnom infrastrukturom i trajnim potrošnim dobrima, materijalnim stanjem (prihodima) kućanstva i ulozi poljoprivrede kao temeljne gospodarske grane u ukupnoj materijalnoj slici ruralnog kućanstva. Za potrebe istraživanja 2012. godine provedena je anketa na uzorku od 170 ispitanika u dobi od 18 do 60 godina, s podjednakim brojem muškaraca i žena.
\end{abstract}

U hrvatskom selu 1960-ih godina započinje modernizacija u području stanovanja izgradnjom komunalne infrastrukture, značajnim poboljšanjem u kvaliteti izgradnje kuća, povećanjem stambenog prostora, ali i usvajanjem modernih sredstava za rad

1 Prvi dio rezultata iznesen je u radu Klempić Bogadi, S., Podgorelec, S. i Šabijan, M. (2015.). Hrvatsko selo na početku 21. stoljeća - studija slučaja općina Gornja Rijeka. Sociologija $i$ prostor, 53 (2): 139-161. 
u kućanstvu. Veličina stambenog prostora, opremljenost kućanstava elementarnom infrastrukturom i trajnim potrošnim dobrima u naseljima općine Gornja Rijeka na zadovoljavajućoj je razini i može se mjeriti s onom u gradskim sredinama.

Materijalno stanje kućanstava u općini Gornja Rijeka nije zadovoljavajuće jer više od pola kućanstava ima ukupne prihode manje od prosječne hrvatske plaće te većina ispitanika procjenjuje da svojim prihodima teško može zadovoljiti sve mjesečne potrebe svog kućanstva.

Poljoprivreda, premda više nije glavni izvor prihoda seoskog stanovništva, još je uvijek važan izvor materijalne sigurnosti, čimbenik u načinu cjelokupnog života seoske zajednice, prije svega u organizaciji svakodnevnice i korištenju prostora.

Ključne riječi: selo, općina Gornja Rijeka, kvaliteta života, stanovanje, infrastruktura, materijalno stanje, poljoprivreda.

\section{Uvod}

U raspravama o načinu života stanovništva u određenim prostorima postignuta je visoka razina suglasnosti znanstvenika da transformacija suvremenih društava čini granicu među konceptima ruralno - urbano, s obzirom na njihove temeljne karakteristike, sve fluidnijom. Ta granica, ako se prostore promatra funkcionalno, nikada i nije bila posve čvrsta ili jasna. Naime za definiciju ruralnog prostora koriste se različiti kriteriji. Prije svega to su kriteriji vezani uz karakteristike fizičkog prostora: vrsta naselja ${ }^{2}$ (Župančić, 2002.), područja koja uključuju pejzaž vezan uz temeljne gospodarske djelatnosti poljoprivredu (Štambuk, 1991.), stočarstvo i šumarstvo ili pak veličina populacije i gustoća naseljenosti, koja je uvijek niža nego u urbanim naseljima. Pejnović ruralni prostor definira kao geoprostorni kompleks izvangradskih područja koji karakteriziraju polifunkcionalnost, složena socijalno-ekonomska struktura i heterogen (mozaičan) pejzaž (Lukić, 2012.). No, uz geografske atribute, podjednako su važni i kriteriji kojima se opisuje društveni aspekt prostora, točnije ruralno se određuje prema načinu života stanovništva, društvenim, moralnim i kulturnim vrijednostima, ulozi tradicije u svakodnevnom životu, odnosu stanovnika prema krajobrazu ${ }^{3}$ i „Životnom stilu usklađenom s organskim životom zajednice“ (Brown i Schafft, 2011.:5). Prema Bengsu i Zonneveldu (2002.:287), „ruralni krajobraz sadrži razbacana izgrađena područja kao i raznolike vidljive i nevidljive tehničke infrastrukture“, pri čemu su proizvodne metode i način rada vezani uz poljoprivredu i šumarstvo znatno industrijalizirani i kao takvi imaju bitan utjecaj na prostor. Stoga, nastojeći nadrasti uobičajenu razdiobu na centar (urbano središte) i periferiju (ruralni prostori), europska prostorno razvojna perspektiva uvodi novu koncepciju javne politike temeljenu na policentričnosti i urbano-ruralnom partnerstvu.

2 Sela, manji gradovi i „zone polifunkcionalnih namjena i profila koje su [...] sadržajno vezane uz ruralni svijet" (Župančić, 2002::36).

3 Nematerijalni koncept koji ruralno smješta u područje idealiziranog, imaginacije (Halfacree, 1996.). 
Kada pišu o kvaliteti života zemalja Europske unije, znanstvenici naglašavaju svojevrsnu promjenu odnosa između ruralnih i urbanih područja (Bengs i Zonneveld, 2002.), i to prije svega u dimenzijama rada (pretežno vezana uz grad) i stanovanja (nešto češće nego ranije vezana uz selo), mjesta rada (postupno smanjenje gotovo isključiva pritiska na grad) i odmora/zabave/rekreacije (sve češće u ruralnom prostoru), proizvodnje hrane (u seoskom području) i opskrbe poljoprivrednim proizvodima (gradskog stanovništva) itd. Dakle razmatraju se razne vrste promjena vezane uz stanovništvo (i to prije svega novi oblici mobilnosti i njihove posljedice), zatim lokalno gospodarstvo, uvjeti i tržište stambenog prostora, ali i razvoj ruralnih politika. Tako prema Brereton i sur. (2011.:204), premda je u ruralnim prostorima zemljište još uvijek u najvećoj mjeri namijenjeno poljoprivredi ${ }^{4}$, ona gotovo nigdje više nije temeljna gospodarska grana. To potvrđuju i podaci Programa ruralnog razvoja Republike Hrvatske za razdoblje 2014. - 2020. (2015.:122) prema kojima „[u] posljednjih nekoliko godina udio poljoprivrednog sektora u BDP-a i udio zaposlene radne snage slijedi negativan trend. Poljoprivredni sektor u ukupnom BDP-u ${ }^{5}$ čini 5,5\% dok udio zaposlenih u poljoprivredi čini 13,8\% od ukupne radne snage. Negativna gospodarska i populacijska kretanja odrazili su se i na to da sve veći broj obiteljskih gospodarstava više ne mogu ekonomski održivo poslovati samo od primarne poljoprivredne proizvodnje bez dodatnog prihoda na gospodarstvu." Odnosno, žele li ruralni prostori preživjeti u suvremenim uvjetima transformacije, moraju daljnji razvoj temeljiti na postulatima održivosti osnažujući ekonomske mogućnosti pomicanjem od nekada primarne industrije - poljoprivrede, koja je gotovo svuda u postupnom padu, prema novim oblicima proizvodnje (McCarthy, 2005.).

Promjena temeljnih izvora prihoda ruralnog stanovništva, ali i novi oblici i/ili smjerovi mobilnosti i urbanog i ruralnog stanovništva rezultiraju postupnim promjenama u načinu korištenja ruralnog prostora. Promatramo li promjene prije svega u hrvatskom društvu (Seferagić, 2000., 1993.), nakon polustoljetnog uglavnom znatnog iseljavanja iz ruralnih područja zadnjih desetljeća bilježi se i stanovito useljavanje u ruralni prostor. Točnije, povratak stanovnika koji su iselili uglavnom zbog školovanja, zapošljavanja ili boljih uvjeta života u urbanim dijelovima zemlje ili inozemstva i koji se vraćaju u ruralna naselja uglavnom iz triju razloga: po umirovljenju iz gradova u kojima su proveli radni vijek, zbog dugotrajne gospodarske krize i gubitka posla u gradovima u kojima su živjeli ili zbog izgradnje i useljenja u kuće za odmor koje se nalaze u ruralnim prostorima. Promatraju li se neki hrvatski ruralni prostori, takvih je primjera najviše na hrvatskim otocima (Podgorelec i Klempić Bogadi, 2013.) ili u ruralnoj okolici hrvatskih gradova (Klempić i Podgorelec, 2009.), a razlozi su nerijetko jeftinije stanovanje, mogućnost ostvarenja sekundarnog izvora prihoda od rada na okućnici, polju ili, kada je riječ o otocima i priobalnom prostoru - ribarenja,

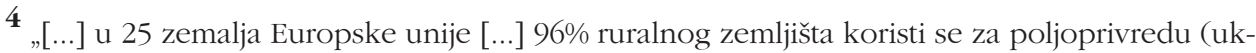
ljučujući i šumarstvo), ali samo 13\% stanovništva zaposleno je u poljodjelstvu, koje proizvodi samo 6\% bruto vrijednosti [...]" (OECD, 2006.).

5 Udio poljoprivrede, šumarstva i ribarstva u BDP-u prema posljednjim dostupnim podacima (za 2014.) iznosio je 3,5\% (Godišnji bruto domaći proizvod za 2014. (ESA 2010.), Priopćenje 12.1.4., DZS, Zagreb, 2016.). 
rješavanje stambenog pitanja ostavljanjem nekretnine u gradu mlađem naraštaju, nove informacijske i komunikacijske tehnologije koje omogućavaju preseljenje u ruralni prostor i rad na daljinu, izgradnja prometnica i razvoj javnog prijevoza koji omogućavaju lakše komutiranje stanovništva, smireniji život u skladu s prirodom, viša razinu sigurnosti i dr.

Analizirajući ulogu prostora pri procjeni kvalitete života Brereton, Clinch i Ferreira (2008) zaključuju da prostorna dimenzija ima važnu ulogu pri određivanju ukupne kvalitete života pojedinca. Visoka značajnost prostornih varijabli potvrdila je da prostorna struktura i odnosi te okoliš imaju veći utjecaj na zadovoljstvo životom no što se to ranije mislilo, točnije podjednako koliko i socioekonomski ((ne)zaposlenost) i sociodemografski čimbenici (bračni status).

Kvaliteta Života, kao i pojam ruralnog, složeni je koncept koji odlikuje višedimenzionalnost, razlika u pristupima različitih znanstvenih disciplina i/ili znanstvenika, ali i različitih društava, a rezultat čega je nepostojanje jedinstvene definicije koncepta, pa stoga i istih dimenzija i indikatora kojima se mjere. Uobičajena je primjena dvaju pristupa: mjerenje kvalitete života s pozornošću na pojedinčevu procjenu i na pokazatelje uvjeta života koji oblikuju okoliš i kulturu nekog društva (Megone, 1990.). Prema Faheyju, Nolanu i Whelanu (2003.), kvalitetu života moguće je promatrati iz triju različitih kutova: iz pozicije pojedinačne životne situacije, pri čemu su odlučujući uvjeti pojedinčeva života i njegov osobni doživljaj (prosudba) (Pacione, 2003.); kao višedimenzionalni koncept, pri čemu se opisuju razne domene života i njihov međusobni odnos; kao suodnos objektivnih i subjektivnih pokazatelja, odnosno pojedinčevu percepciju i vrednovanje objektivnih uvjeta života. Svaka od definicija nužno ima svoje nedostatke i svaka pokušava pronaći objektivne i jasne kriterije moguće operacionalizacije ${ }^{6}$.

Za potrebe ovoga rada podaci prikupljeni istraživanjem kvalitete života na uzorku stanovništva općine Gornja Rijeka bit će analizirani s obzirom na ruralne značajke prostora, uzevši u obzir objektivne uvjete (veličinu populacije i gustoću naseljenosti prostora), strukturu naselja i temeljnu djelatnost - poljoprivredu.

\subsection{Osnovna sociogeografska i demografska obilježja istraživanog prostora}

6 Primjerice prvo europsko istraživanje kvalitete života stanovništva (Quality of life in Europe, 2003.:1) usmjerilo je pozornost na šest područja: zaposlenost, ekonomske izvore, obitelj i kućanstvo, život zajednice i društvenu participaciju, zdravlje i zdravstvenu skrb te znanje,

obrazovanje i učenje.

Općina Gornja Rijeka ruralno je područje smješteno podno Malog Kalnika na zapadnoj granici Koprivničko-križevačke županije. Najbliži su gradski centar 16 km udaljeni Križevci. Udaljenost od najbližeg gradskog središta i slabija prometna povezanost utjecali su na očuvanje temeljnih karakteristika ruralnosti prostora općine i na svojevrstan način onemogućile useljavanje iz Križevaca i formiranje općine kao suburba- 
nog prstena. Prema Zakonu o područjima posebne državne skrbi (NN 86/08, 57/11, 51/13, 148/13, 76/14, 18/15), općina Gornja Rijeka prema stupnju gospodarskog i društvenog razvoja pripada trećoj skupini područja posebne državne skrbi Republike Hrvatske, čija je karakteristika da zaostaju u razvoju po ekonomskim, strukturnim i demografskim kriterijima razvijenosti.

Slika 1.

Naselja općine Gornja Rijeka

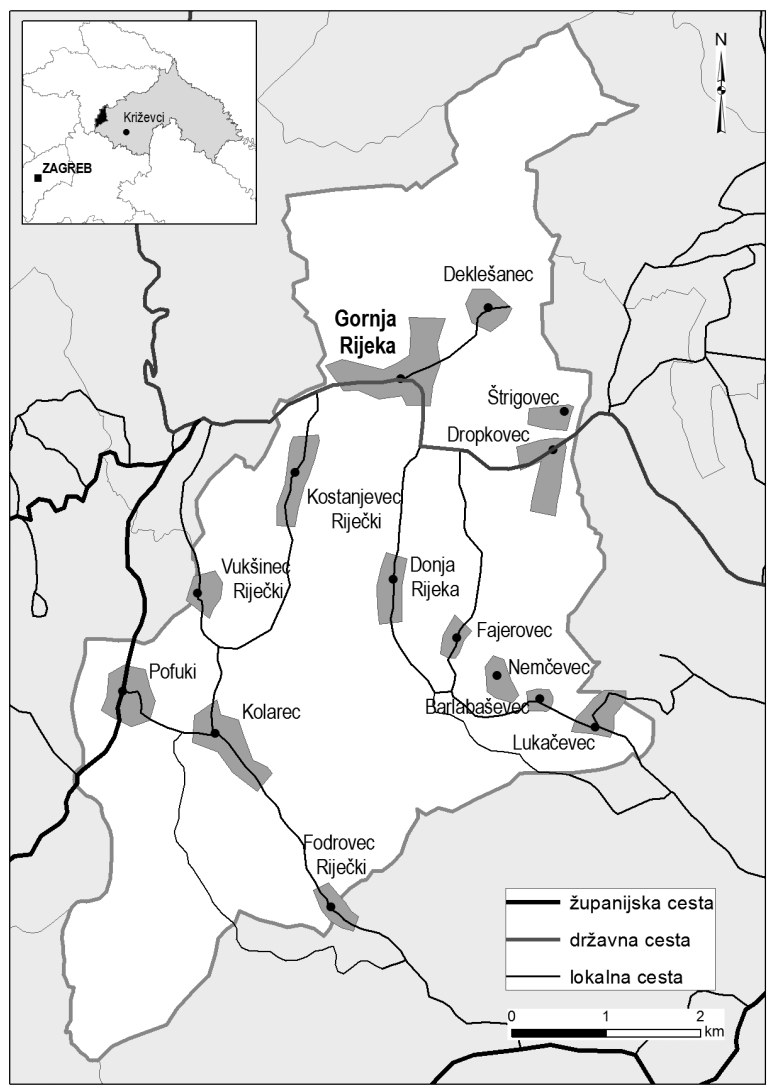

Izvor: autorice

Prema podacima posljednjeg popisa stanovništva (2011.), na području od 32,72 $\mathrm{km}^{2}$ u 503 kućanstava živjelo je ukupno 1.779 stanovnika. Po prostoru koji zauzima, broju stanovnika kao i po prosječnoj gustoći naseljenosti sa 54,4 stanovnika na $\mathrm{km}^{27}$ općina Gornja Rijeka jedna je od najmanjih. Područje općine čini 14 izrazito malih naselja okupljenog tipa, smještenih periferno u odnosu na općinsko središte, od kojih u gotovo polovici živi manje od 100 stanovnika (17,6\% ukupnog stanovništva općine). Prema brojnosti stanovnika najveća su naselja Donja Rijeka

${ }^{7}$ Prosječna je gustoća naseljenosti Koprivničko-križevačke županije 66,1 st./km² i niža je od prosječne naseljenosti Republike Hrvatske od 75,7 st. $/ \mathrm{km}^{2}$. 
(s 218 stanovnika), Kostanjevec Riječki (267) i Gornja Rijeka (340). Slijede (svrstani od većeg prema manjem broju stanovnika) Pofuki i Dropkovec (od 151 do 200 stanovnika), pa Kolarec i Deklešanec (od 101 do 150 stanovnika), Fajerovec, Fodrovec Riječki i Vukšinec Riječki (od 51 do 100 stanovnika) te Barlabaševec, Nemčevec, Lukačevec i Štrigovec s manje od 50 stanovnika. Struktura je naselja tipična za ruralni prostor - zbijenog tipa s većinom obiteljskih kuća okrenutih prema prometnici, dok su iza njih, na strani dvorišta, gospodarske zgrade i u nastavku poljoprivredne površine. Svi popisi stanovništva bilježe kontinuirani pad broja stanovnika, s negativnom prirodnom promjenom i stalno rastućim udjelom starog stanovništva.

\section{Istraživanje}

\subsection{Metoda istraživanja i uzorak}

Prema karakteristikama pejzaža, gustoći naseljenosti, glavnoj gospodarskoj aktivnosti (poljoprivredi), prostornom rasporedu stambenih objekata i gospodarskih zgrada, prometnica i razini usluga naselja općine Gornja Rijeka pripadaju kontinentalnom ruralnom prostoru Hrvatske i kao takva predstavljaju dobar primjer studije slučaja za cilj koji je nacrtom istraživanja bio postavljen - procjena objektivnih i subjektivnih domena kvalitete života stanovništva radno aktivne dobi u ruralnim prostorima.

Istraživanje je provedeno metodom ankete krajem 2012. godine u svim naseljima općine Gornja Rijeka na prigodnom uzorku od 170 ispitanika (gotovo 10\% ukupnog stanovništva općine) u dobi od 18 do $60^{8}$ godina. Anketom je bio obuhvaćen jednak broj muškaraca (50\%) i žena (50\%). Struktura uzorka prema dobi bila je: od 18 do 29 godina 55 anketiranih, od 30 do 39 njih 62, od 40 do 49 godina starosti 37 ispitanika i u najstarijem razredu (50 do 60) 16.

Izabrane domene kvalitete života stanovništva općine Gornja Rijeka koje ce biti analizirane u ovome radu su: kvaliteta stanovanja, opremljenost stanova elementarnom infrastrukturom i trajnim potrošnim dobrima, materijalno stanje te poljoprivreda kao temeljna gospodarska aktivnost i njezina povezanost s materijalnim blagostanjem.

8 Većina stanovnika ruralnih područja sa 60 godina ostvaruje ili je već ostvarila pravo na mirovinu, s obzirom na rani ulazak u svijet rada (pretežno završeno niže i srednje obrazovanje). 


\section{Rezultati i rasprava}

\subsection{Stanovanje u ruralnim područjima}

Prema Cumminsu (1997.), za uvid u materijalno blagostanje pojedinca treba zbrojiti podatke o njegovu prihodu, kvaliteti stanovanja i osobnom posjedovanju. Za potrebe ovoga rada analiza prikupljenih podataka istraživanja započet će uvidom u kvalitetu stanovanja stanovništva ruralne općine Gornja Rijeka.

Stanovanje je jedna od najvažnijih domena u istraživanjima kvalitete života kako u urbanim tako i u ruralnim prostorima i povezano je s općim socioekonomskim i sociokulturnim procesima u prostoru. Seferagić (1990.:137) shvaća stanovanje kao mogućnost cjelovitog svakodnevnog života u stanu i stambenoj okolini, a ono obuhvaća uže stambene uvjete (stan) i šire stambene uvjete (stambenu okolinu).

Nepovoljne stambene prilike karakterizirale su hrvatsko selo sve do razdoblja nakon Drugog svjetskog rata, kada počinje značajniji zaokret i napredak u stambenom standardu. „Stambene su zgrade većinom bile građene od lošeg materijala, stambeni je prostor bio skučen - s obzirom na veliki broj ukućana, a u nekim je dijelovima zemlje bio čak i neodijeljen od prostora za stoku; taj je prostor imao malo soba (ali višefunkcionalnih) sa skoro nikakvom opremljenošću instalacijama itd." (Hodžić, 1976.:52-53). I dok su još sredinom 20. stoljeća seoske kuće bile vrlo male kvadrature i s malim brojem soba u kojima su živjele višegeneracijske obitelji, s modernizacijom sela 1960-ih počinje izgradnja novih obiteljskih kuća veće kvadrature i s većim brojem soba, dok se istovremeno smanjuje broj višegeneracijskih kućanstava i sve je izraženija težnja da jedna obitelj živi u jednom stanu. Nepoljoprivredno stanovništvo koje je ostalo živjeti na selu, a počelo je raditi u gradu donosilo je inovacije i promjene u seoski život. Težili su postići životni standard stanovnika u gradovima, pa su prvi počeli s modernizacijom stambenog prostora uvođenjem infrastrukture, ali i s kupovanjem kućanskih uređaja. Tijekom vremena došlo je do napretka u izgradnji elementarne komunalne infrastrukture, prometnica i općenito kvalitete i veličine stambenih prostora, te je znatno smanjen udio kućanstava koja žive u neprimjerenim stambenim uvjetima.

Početkom 1990-ih postoje znatne razlike u stanovanju između grada i sela - dok je u gradu bolja opremljenost stanova i okoline, na selu stanovi imaju veći broj soba i veću kvadraturu, a bolji su i ekološki uvjeti života (Seferagić, 1990.:158). I desetljeće kasnije stanovi na selu, u usporedbi s gradskima, imaju ukupno viši stambeni status s obzirom na veću ukupnu stambenu površinu, veću prosječnu stambenu površinu po članu kućanstva i veći broj soba (Hodžić, 2002.).

Prema podacima Popisa stanovništva, kućanstava i stanova iz 2011., na području općine Gornja Rijeka ukupno je registrirano 645 stanova, od toga 487 nastanjenih, površine $37.456 \mathrm{~m}^{2}$, što daje prosječnu površinu stana od $76,9 \mathrm{~m}^{2}$, zatim 49 stanova za odmor i rekreaciju, dok se 109 stanova ukupne stambene površine $5924 \mathrm{~m}^{2}$ vodi kao nenastanjene ili napuštene, što je dobar stambeni pokazatelj ruralne depopulacije.

9 Popis stanovništva, kućanstava i stanova 2011., DZS, Zagreb, www.dzs.hr. 
Analiza godine izgradnje nastanjenih stanova pokazuje da je polovica stambenog fonda općine Gornja Rijeka izgrađena 1970-ih (30,2\%) i 1980-ih (20,1\%), u doba već poodmakle depopulacije, koja je na području te općine počela u drugoj polovici 1950-ih godina. ${ }^{10} \mathrm{~S}$ obzirom da u tim razdobljima nije došlo do doseljavanja novog stanovništva koje bi trebalo novi stambeni prostor, očito je riječ o izgradnji novih kuća postojećeg stanovništva, ali i odvajanju obitelji iz višegeneracijskih kućanstava.

Tablica 1.

Starost stambenog fonda općine Gornja Rijeka (nastanjeni stanovi) 2011. godine

\begin{tabular}{|c|c|c|c|c|c|c|c|c|}
\hline Ukupno & Do 1945. & $\begin{array}{c}1946 .- \\
1960 .\end{array}$ & $\begin{array}{c}1961 .- \\
1970 .\end{array}$ & $\begin{array}{c}1971 .- \\
1980 .\end{array}$ & $\begin{array}{c}1981 .- \\
1990 .\end{array}$ & $\begin{array}{c}1991 .- \\
2000 .\end{array}$ & $\begin{array}{c}\text { 2001. - } \\
\text { 2011. }^{*}\end{array}$ & Nepoznato \\
\hline 487 & 47 & 54 & 77 & 147 & 98 & 45 & 17 & 2 \\
\hline $100,0 \%$ & $9,7 \%$ & $11,1 \%$ & $15,8 \%$ & $30,2 \%$ & $20,1 \%$ & $9,2 \%$ & $3,5 \%$ & $0,4 \%$ \\
\hline
\end{tabular}

* Podaci za 2011. odnose se samo na prva tri mjeseca.

Izvor: Popis stanovništva, kućanstava i stanova 2011., DZS, Zagreb, posebna obrada.

Prema istraživanju (2004.) sobnosti stanova u mreži naselja Hrvatske, najbolja je situacija u selima i seoskim lokalnim centrima, gdje su bile najzastupljenije kuće/stanovi s trima sobama, $(32,2 \%)$, slijede oni s četirima sobama $(24,2 \%)$, dvjema sobama $(20,8 \%)$, pet i više soba $(19,9 \%)$, dok je stambenog prostora s jednom sobom tek 2,9\% (Svirčić Gotovac, 2006.). Podaci iz istraživanja u općini Gornja Rijeka pokazuju da 22,4\% ispitanika živi u obiteljskoj kući/stanu s trima sobama, 34,1\% s četirima sobama, $16,5 \%$ s pet te $14,7 \%$ sa šest i više soba, što ukazuje na činjenicu da većina kućanstava posjeduje stambeni prostor velike sobnosti.

Slika 2.

Stanovi prema broju soba (\%)

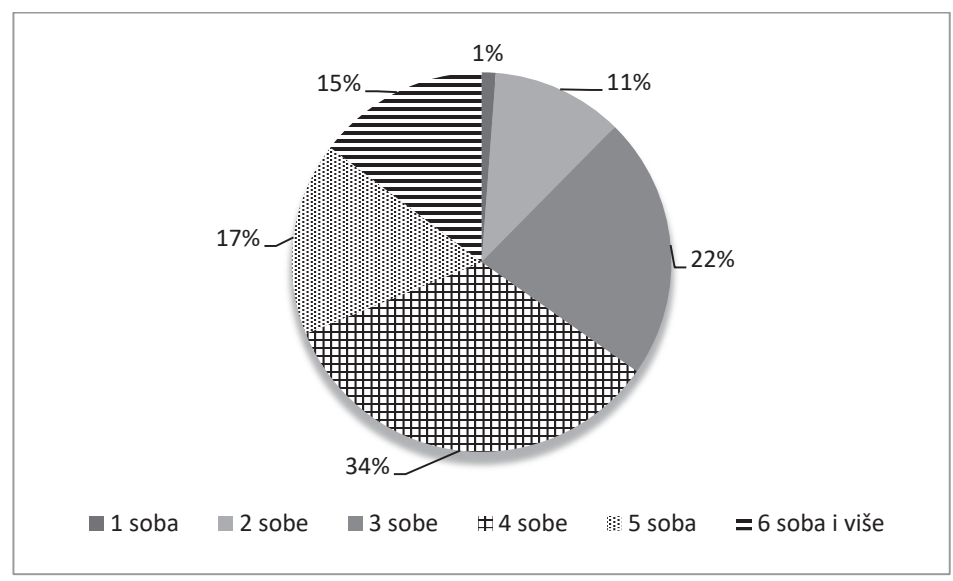

10 U međupopisnom razdoblju 1961. - 1971. naselja te općine izgubila su 14\% ukupnog stanovništva, 1971. - 1981. 8\%, a 1981. - 1991. 13\%, što je bilo rezultat nepovoljnog prirodnog kretanja i iseljavanja. 
Tijekom 1990-ih, zbog privatizacije dotadašnjih društvenih stanova, došlo je do značajnih promjena u vlasništvu stambenog prostora na razini države. Kako su društveni stanovi bili uglavnom locirani u gradskim naseljima, te promjene nisu značajnije utjecale na promjenu vlasništva u ruralnim područjima, gdje su stanovi / obiteljske kuće oduvijek gotovo isključivo u privatnom vlasništvu. Država je imala i ima beznačajnu ulogu u stambenoj izgradnji u ruralnim područjima s obzirom da nije nikakva sredstva ulagala u rješavanje stambenih problema sela. Istraživanjem stambenih uvjeta u općini Gornja Rijeka željelo se ustanoviti i stambeni status ispitanika, točnije tko je vlasnik nekretnine u kojoj trenutno stanuju. Tako gotovo polovica ispitanika, njih 84 ili 49,4\% živi s roditeljima u njibovoj kući, 34,7\% (59) ispitanika su vlasnici nekretnine u kojoj stanuju i nemaju kredit za nju, dok njih 8,8\% (15) još uvijek otplaćuje kredit za kuću u kojoj živi. Svega su troje ispitanika podstanari (1,8\%), dok je njih 9 ili 5,3\% u kategoriji nešto drugo, primjerice žive s bakom i djedom i sl. Stavi li se u odnos varijabla dob i stambeni status, proizlazi da 46 od 55 ispitanika starih između 18 i 29 godina još uvijek živi s roditeljima u njihovoj kući. Obrazac kasnog odlaska mladih iz roditeljskog doma sličan je na selu kao i u gradu, i to čak i nakon što se zaposle i/ili stupe u brak. Ti rezultati potvrđuju nalaze nekih drugih istraživanja (Akrap i Čipin, 2006.:112), prema kojima u Hrvatskoj postoji trend produženog života $s$ roditeljima, a razlozi su prije svega nezaposlenost mladih (nerazvijeno gospodarstvo i nedostatak novih radnih mjesta) i nedostatna stambena opskrba, ali i tradicionalni tip obiteljskih odnosa (obitelj-gnijezdo). Naime prema istraživanjima „[u] južnoeuropskim zemljama ${ }^{11}$ obitelj je i dalje središnja institucija socijalizacije i čvrsta mreža mikrosolidarnosti“" (Moreno, 2002.:2), koja se iskazuje uzajamnim pomaganjem, ali nerijetko i (pre)zaštitničkim odnosom roditelja prema (odrasloj) djeci.

\subsection{Opremljenost ruralnih kućanstava elementarnom infrastrukturom $i$ trajnim potrošnim dobrima}

Opremljenost kućanstva elementarnom infrastrukturom i trajnim potrošnim dobrima vrlo je važna za organizaciju i svakodnevni život ljudi. D. Seferagić (1993.:229) opremljenost kućanstava klasificira na: elementarnu (kvaliteta i opremljenost stana osnovnom infrastrukturom), srednju (tzv. strojevi koji štede ljudski rad) i luksuznu (stvari o kojima ne ovisi život, ali ga oplemenjuju i kultiviraju).

Iako je opremljenost elementarnom infrastrukturom u naseljima općine Gornja Rijeka dobra jer sva kućanstva imaju električnu struju i velika većina tekuću vodu (96,5\%), uočljiv je problem s kanalizacijskom mrežom (tablica 2.). Taj problem imaju i brojna gradska naselja, ali ovdje čak 35,9\% stanova uopće nema izgrađenu kanalizaciju te ispušta sanitarno-fekalne vode u cestovne seoske grabe i slične lokalitete koji ugrožavaju lokalne vodotoke. S obzirom da ne postoji javna kanalizacijska mreža, 64,1\% ispitanika koji navode da imaju kanalizaciju pod tim, u stvari, podrazumijeva septičke jame. Osim toga još uvijek gotovo 10\% kućanstava nema kupaonicu niti WC s ispiranjem, što bi u 21. stoljeću trebao biti minimalan standard stanovanja.

11 Kojima pripada i Hrvatska. 
Element infrastrukturne opremljenosti stambenog prostora s najmanjim udjelom zastupljenosti centralno je grijanje. Tek 62,9\% ispitanika ima ugrađeno centralno grijanje, što ne iznenađuje jer plinifikacija u općini nije provedena. S druge strane, taj udio znatno je viši u usporedbi s ranije provedenim istraživanjem na razini Hrvatske 1996. godine, kada je samo 9,8\% seoskih kućanstava imalo centralno grijanje (Hodžić, 2002.).

Tablica 2.

Opremljenost kućanstva elementarnom infrastrukturom

\begin{tabular}{|c|c|c|c|c|c|c|}
\hline & \multicolumn{2}{|c|}{ Ukupno } & \multicolumn{2}{|c|}{$\mathrm{Da}$} & \multicolumn{2}{|c|}{$\mathrm{Ne}$} \\
\hline & $\mathrm{N}$ & $\%$ & $\mathrm{~N}$ & $\%$ & $\mathrm{~N}$ & $\%$ \\
\hline Tekuća voda & 170 & 100,0 & 164 & 96,5 & 6 & 3,5 \\
\hline Električna struja & 170 & 100,0 & 170 & 100,0 & - & - \\
\hline Kanalizacija & 170 & 100,0 & 109 & 64,1 & 61 & 35,9 \\
\hline Kupaonica & 170 & 100,0 & 155 & 91,2 & 15 & 8,8 \\
\hline WC (s ispiranjem) & 170 & 100,0 & 158 & 92,9 & 12 & 7,1 \\
\hline Centralno grijanje & 170 & 100,0 & 107 & 62,9 & 63 & 37,1 \\
\hline Telefon & 170 & 100,0 & 160 & 94,1 & 10 & 5,9 \\
\hline Priključak na Internet & 170 & 100,0 & 124 & 72,9 & 46 & 27,1 \\
\hline
\end{tabular}

Vrlo je visok udio stanova s telefonom (94,1\%), ali i s priključkom na Internet (72,9\%). Prema podacima na razini Hrvatske za 2015. (DZS, 2015), 77\% kućanstava imalo je osobno računalo i isto toliko pristup Internetu. Razvoj informacijskih i komunikacijskih tehnologija posebno je bitan u ruralnim područjima jer je to jedan od načina premošćivanja ograničavajućih ${ }^{12}$ uvjeta života u ruralnim prostorima. Dakle suvremene komunikacijske tehnologije omogućuju višu raznu povezanosti ruralnog stanovništva, veću dostupnost znanja i informacija kao i veću mogućnost rada od kuće (zapošljavanja ili samozapošljavanja).

Tijekom proteklih desetljeća značajno se promijenio standard opremljenosti kućanstava, pa su uređaji bijele tehnike, koji su u 1960-ima bili svojevrstan luksuz, danas standard i u seoskim kućanstvima. Opremljenost kućanstava uređajima kao što su zamrzivač, hladnjak, stroj za pranje rublja i električna/plinska pećnica na zadovoljavajućoj je razini (više od 90\%, tablica 3.). Jedini uređaj koji svi ispitanici imaju u kućanstvu je zamrzivač, što je moguće objasniti činjenicom da je na selu mreža trgovina i opskrba uvijek bila znatno lošija nego u gradovima, pa je stanovništvo prisiljeno raditi zalihe prehrambenih namirnica. Osim toga većina ima okućnicu ili poljoprivredno imanje pa, ako i ne proizvode za prodaju, imaju voće, povrće ili meso za vlastite potrebe te ih sezonski spremaju u zamrzivače kako bi ih mogli trošiti tijekom cijele godine.

12 Periferni položaj i nerijetko slabija prometa povezanost, posebice zbog neadekvatno razvijenog javnog prijevoza, nedostatka radnih mjesta, nedostupnosti raznih usluga i sadržaja vezanih za općinska i /ili urbana središta i dr. 
Na znatno je nižoj razni opremljenost kućanstava uređajima kao što su sušilica za rublje i perilica za pranje posuđa. Tako sušilicu rublja ima tek svaki deseti ispitanik (10,6\%), a perilicu posuđa svaki treći (36,5\%). Opremljenost kućanskim aparatima uvijek je individualna odluka, koja ovisi kako o potrebama kućanstva tako u velikoj mjeri i o financijskim mogućnostima. Prema podacima u istraživanju, perilica suđa i sušilica za rublje predstavljaju još uvijek svojevrsnu nadgradnju u opremljenosti relativno rijetkih seoskih kućanstava.

Televizor imaju gotovo sva kućanstva i on je iznimno važan u relativno izoliranim ruralnim kućanstvima kao glavni izvor informacija i razonode. Pritom satelitsku antenu ili kabelsku televiziju ima 51,2\% ispitanika. Opremljenost kućanstava računalima zadovoljavajuća je, pa tako 69,4\% ispitanika ima stolno računalo i 42,9\% prijenosno računalo. ${ }^{13}$ Za razliku od računala, zamjetan je malen broj ispitanika koji imaju više od 100 knjiga kod kuće - njih svega 11. Razloga za to vjerojatno je više - od prosječno niže ${ }^{14}$ obrazovne strukture stanovnika u ruralnim krajevima do trenda ${ }^{15}$ sve manjeg broja stanovnika Hrvatske koji čitaju knjige kao i sve manjeg broja kupaca knjiga (pad kupovne moći prosječnog stanovnika, relativno visoka cijena knjige zbog malog tržišta, sve manji interes za knjigu kao medij).

Tablica 3.

Opremljenost kućanstva trajnim potrošnim dobrima

\begin{tabular}{|l|c|c|c|c|c|c|}
\hline \multirow{2}{*}{} & \multicolumn{2}{|c|}{ Ukupno } & \multicolumn{2}{c|}{ Da } & \multicolumn{2}{c|}{ Ne } \\
\cline { 2 - 7 } & $\mathrm{N}$ & $\%$ & $\mathrm{~N}$ & $\%$ & $\mathrm{~N}$ & 6,5 \\
\hline Električna/plinska pećnica & 170 & 100,0 & 159 & 93,5 & 11 & 1,8 \\
\hline Hladnjak & 170 & 100,0 & 167 & 98,2 & 3 & - \\
\hline Zamrzivač & 170 & 100,0 & 170 & 100 & & 2,4 \\
\hline Stroj za pranje rublja & 170 & 100,0 & 166 & 97,6 & 4 & 89,4 \\
\hline Sušilica za rublje & 170 & 100,0 & 18 & 10,6 & 152 & 63,5 \\
\hline Perilica za pranje posuđa & 170 & 100,0 & 62 & 36,5 & 108 & 48,8 \\
\hline Satelitska antena/kabelska TV & 170 & 100,0 & 87 & 51,2 & 83 & 30,6 \\
\hline Osobno računalo & 170 & 100,0 & 118 & 69,4 & 52 & 57,1 \\
\hline Prijenosno računalo & 170 & 100,0 & 73 & 42,9 & 97 & 93,5 \\
\hline Biblioteka (više od 100 knjiga) & 170 & 100,0 & 11 & 6,5 & 159 & 2 \\
\hline
\end{tabular}

13 Četrdeset kućanstava uopće nema računalo.

14 The New Rural Paradigm: Policies and Governance, OECD, 2006:12

15 Posljednji podaci istraživanja agencije GfK pokazali su da manje od polovine stanovništva Hrvatske uopće čita knjige i da njihov broj kontinuirano opada (s 56\% u 2011. na 47\% u 2016.), a smanjuje se i broj stanovnika koji kupuju knjige (2005. 32\%, a 2016. 22\%). (Večernji list, Denis Derk „Samo 47 posto građana Hrvatske pročitalo barem jednu knjigu u posljednjih godinu dana - Više od prosjeka čita se u Zagrebu, Primorju i Dalmaciji. http://www.vecernji. hr/knjige/samo-47-posto-gradana-hrvatske-procitalo-barem-jednu-knjigu-u-posljednjih-godinu-dana-1078522, 15.12.2016). 


\subsection{Zadovoljstvo ispitanika kvalitetom stambenih uvjeta}

U svrhu utvrđivanja zadovoljstva uvjetima stanovanja u općini Gornja Rijeka ispitanici su ocjenama od 1 (izrazito nezadovoljan) do 5 (izrazito zadovoljan) ocjenjivali pet elemenata koji na neki način određuju kvalitetu stambenih uvjeta. Prosječne vrijednosti stupnja zadovoljstva stanovanja pokazuju da ispitanici u najvećoj mjeri nisu ni zadovoljni ni nezadovoljni pojedinim kategorijama uvjeta stanovanja (tablica 4.).

Tablica 4.

Zadovoljstvo stambenim uvjetima

\begin{tabular}{|c|c|c|c|c|c|c|c|}
\hline & 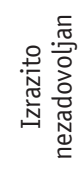 & 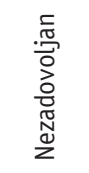 & 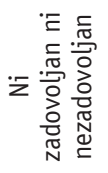 & 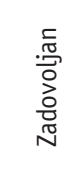 & 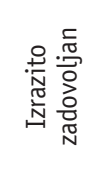 & M & SD \\
\hline Lokacijom & $2,4 \%$ & $5,3 \%$ & $27,6 \%$ & $47,1 \%$ & $17,6 \%$ & 3,72 & 0,897 \\
\hline $\begin{array}{l}\text { Blizinom stanice javnog } \\
\text { prometa }\end{array}$ & $6,5 \%$ & $15,9 \%$ & $30,6 \%$ & $30,0 \%$ & $17,1 \%$ & 3,35 & 1,133 \\
\hline $\begin{array}{l}\text { Opskrbljenošću okolicom } \\
\text { (dućan, ljekarna, ambulanta) }\end{array}$ & $13,5 \%$ & $17,6 \%$ & $31,8 \%$ & $30,0 \%$ & $7,1 \%$ & 2,99 & 1,144 \\
\hline $\begin{array}{l}\text { Susjedstvom (međuljudskim } \\
\text { odnosima) }\end{array}$ & $7,1 \%$ & $7,1 \%$ & $25,9 \%$ & $46,5 \%$ & $13,5 \%$ & 3,52 & 1,045 \\
\hline $\begin{array}{l}\text { Lokalnom samoupravom i } \\
\text { njihovim akcijama }\end{array}$ & $15,3 \%$ & $18,8 \%$ & $37,1 \%$ & $22,9 \%$ & $5,9 \%$ & 2,85 & 1,118 \\
\hline
\end{tabular}

Ispitanici su najzadovoljniji lokacijom, tj. mjestom stanovanja $(\mathrm{M}=3,72, \mathrm{SD}=0,897)$, pa je 47,1\% zadovoljnih i 17,6\% izrazito zadovoljnih. Svjesni su ekoloških vrijednosti prostora u kojem žive - očuvane prirode, čiste vode i zraka, niske razine buke i općenito još uvijek ekološki vrlo kvalitetnog okoliša.

Nakon lokacije stambenog objekta u kojem žive, sljedeće što ih čini zadovoljnima je susjedstvo i općenito međuljudski odnosi $(\mathrm{M}=3,52, \mathrm{SD}=1,045)$, pri čemu je $46,5 \%$ zadovoljno, a 13,5\% izrazito zadovoljno. Ti rezultati u skladu su i s nekim ranije provedenim istraživanjima o kvaliteti života u ruralnim područjima u Republici Hrvatskoj. U istraživanju provedenom u 120 sela u Hrvatskoj, na uzorku 941 stanovnika starog od 25 do 45 godina, pri ocjeni kvalitete životnih uvjeta u naselju najvišu prosječnu ocjenu ispitanici su dali međususjedskim odnosima (53,5\% ispitanika smatra ih odličnim i dobrim) što potvrđuje ,[...] da su međususjedski odnosi i danas u samoj srži lokalne integracije i da se susjedstvo kao neformalno, dobrovoljno zajedništvo u velikoj mjeri zadržalo u svakodnevici seoskoga života“ (Žutinić i sur., 2010.:146). U seoskoj zajednici međusobni su odnosi članova jednostavniji, otvoreniji i neposredniji, pa usprkos promjenama nekih tradicionalnih vrijednosti još je uvijek jaka povezanost s rodbinom i susjedima (Hodžić, 2000.; Župančić, 2002.; Lay, 2002.; Podgorelec i Klempić Bogadi, 2013.). Ispitanici su svjesni važnosti očuvanja društvene mreže i dobrih međuljudskih odnosa, te oni predstavljaju bitan čimbenik dobre kvalitete života u ruralnim sredinama. 
Nešto je niže iskazano zadovoljstvo blizinom stanice javnog prijevoza, što je bio sljedeći element ocjenjivanja ( $M=3,35, \mathrm{SD}=1,133)$. Sama blizina stanice autobusa ili vlaka ne govori puno o kvaliteti javnog prijevoza. Dobra povezanost naselja javnim prijevozom (redovitost, frekventnost, mogućnost povratka u istom danu, direktne linije do lokalnih centara i sl.) i dalje je važna i značajno utječe na ukupnu kvalitetu života, posebice učenika i starijeg stanovništva. Međutim s porastom broja stanovnika koji posjeduju automobil javni je prijevoz nešto izgubio na značaju.

Nešto slabije $(\mathrm{M}=2,99, \mathrm{SD}=1,144)$ ispitanici ocjenjuju i opskrbljenost okolice osnovnim sadržajima (trgovine, ambulanta, ljekarna i sl.). Općina Gornja Rijeka područje je raštrkanih manjih naselja te je zdravstvena, kulturna i mreža trgovina i usluga vrlo slabo razvijena, pa su stanovnici većinom ovisni o skromnim sadržajima u općinskom središtu ili nešto boljim sadržajima u gradu Križevcima.

Najlošiju prosječnu ocjenu $(\mathrm{M}=2,85, \mathrm{SD}=1,118)$ ispitanici su dodijelili lokalnoj samoupravi i aktivnostima koje ona provodi. Trećina stanovnika nema mišljenje o tome (niti su zadovoljni niti nezadovoljni), trećina je zadovoljnih i trećina je nezadovoljnih, što znači da dvije trećine mahom ne prepoznaju aktivnosti lokalne samouprave kao pozitivan čimbenik unapređenja kvalitete života. Premda su formalno ovlasti općina ${ }^{16}$ dosta velike, provedba bilo kakvih aktivnosti koje direktno utječu na kvalitetu života građana ovisi o prihodima koje pojedina općina ima. Iako je i u misiji općine Gornja Rijeka naglasak na kvaliteti života ${ }^{17}$, s obzirom na ocjenu građana aktivnosti koje se provode očito nisu u skladu s njihovim očekivanjima.

16

Prema članku 19. Zakona o lokalnoj i područnoj (regionalnoj) samoupravi, NN 33/01, 60/01, 129/05, 109/07, 125/08, 36/09, 36/09, 150/11, 144/12, 19/13, 137/15, „Općine i gradovi u svom samoupravnom djelokrugu obavljaju poslove lokalnog značaja kojima se neposredno ostvaruju potrebe građana, a koji nisu Ustavom ili zakonom dodijeljeni državnim tijelima i to osobito poslove koji se odnose na: uređenje naselja i stanovanje, prostorno i urbanističko planiranje, komunalno gospodarstvo, brigu o djeci, socijalnu skrb, primarnu zdravstvenu zaštitu, odgoj i osnovno obrazovanje, kulturu, tjelesnu kulturu i šport, zaštitu potrošača, zaštitu i unapređenje prirodnog okoliša, protupožarnu i civilnu zaštitu, promet na svom području te ostale poslove sukladno posebnim zakonima. Posebnim zakonima kojima se uređuju pojedine djelatnosti iz stavka 1 . ovoga članka odredit će se poslovi čije su obavljanje općine i gradovi dužni organizirati te poslovi koje mogu obavljati."

17 „Općinska uprava Općine Gornja Rijeka treba putem svojih aktivnosti i usluga unaprjeđivati kvalitetu života i rada na cjelokupnom području, a naročito iz područja: osiguranje uvjeta za obavljanje i razvitak gospodarskih, komunalnih, društvenih i drugih djelatnosti od važnosti za područje općine; prostorno i urbanističko planiranje, te zaštitu i unapređenje prirodnog okoliša; uređenje naselja, stanovanje, komunalne i druge uslužne djelatnosti; primarne zdravstvene zaštite; brigu o djeci, socijalnu skrb, odgoj i obrazovanje; kulturu, tjelesnu kulturu i sport; zaštitu potrošača; zaštitu i unapređenje prirodnog okoliša; protupožarnu i civilnu zaštitu; promet na svom području i upravljanje općinskom imovinom." http://www.gornja-rijeka. $\underline{\mathrm{hr} / \mathrm{misijavizija-i-ciljevi/,}, 07.10 .2016 .}$ 


\subsection{Materijalno stanje stanovništva i važnost poljoprivrede}

Materijalno stanje jedna je od temeljnih objektivnih dimenzija po kojoj se određuje razina kvalitete života pojedinca ili društva.

Količina novca u znatnoj mjeri određuje kvalitetu života ne samo zbog toga što omogućuje zadovoljenje osnovnih potreba već zato što raspolaganje dostatnom količinom novca pojedinca oslobađa brige kako platiti troškove nekih drugih potreba (kao što su obrazovne, kulturne i zabavne), omogućuje mu rješavanje neke izvanredne situacije, plaćanje nekog oblika praktične pomoći i sl. (Gabriel i Bowling, 2004.).

Koliko je financijskih sredstava potrebno za pristojan i ugodan život kućanstva? U tu svrhu ispitanicima je postavljeno pitanje o prosječnim mjesečnim prihodima, čime je ustanovljeno da je polovica ispitanika $(52,3 \%)$ izjavila da njihovo kućanstvo ima prihode manje od $5000 \mathrm{HRK}$, što je bilo niže od prosječne plaće u Hrvatskoj, koja je u trenutku provođenja istraživanja iznosila $5487 \mathrm{HRK}^{18}$, i ukazuje na nepovoljnu financijsku situaciju brojnih kućanstava.

Tablica 5.

Prosječna mjesečna primanja kućanstava, u HRK

\begin{tabular}{|c|c|c|c|c|c|c|c|}
\hline Ukupno & Do 2000 & $\begin{array}{c}2001- \\
3500\end{array}$ & $\begin{array}{c}3501- \\
5000\end{array}$ & $\begin{array}{c}5001- \\
7000\end{array}$ & $\begin{array}{c}7001- \\
9000\end{array}$ & $\begin{array}{c}9001- \\
11.000\end{array}$ & $\begin{array}{c}\text { Više od } \\
11.001\end{array}$ \\
\hline 170 & 16 & 34 & 39 & 28 & 24 & 17 & 12 \\
\hline $100,0 \%$ & $9,4 \%$ & $20,0 \%$ & $22,9 \%$ & $16,5 \%$ & $14,1 \%$ & $10 \%$ & $7,1 \%$ \\
\hline
\end{tabular}

Najviše ispitanika $(61,2 \%)$ živi od plaće, 15,9\% nema prihode, 11,2\% ima prihode od poljoprivrede, 4,7\% mirovinu, 3,5\% socijalnu naknadu, 2,4\% stipendiju i 1,2\% živi od sezonskog rada. Time je i na primjeru općine Gornja Rijeka potvrđena teza (Brereton i sur., 2011.:204) da iako je prostor ili preciznije pejzaž općine još uvijek u velikoj mjeri namijenjen poljoprivredi, ona više nije temeljna gospodarska grana od koje stanovništvo živi. Promatrajući hrvatski ruralni prostor u cjelini, rezultat je to višedesetljetne deagrarizacije i sve brojnijeg zapošljavanja stanovništva u nepoljoprivrednim djelatnostima (u sekundarnom i tercijarnom sektoru).

Osim prihoda pokazatelj je materijalnog stanja i posjedovanje imovine. Izrazito malen broj ispitanika ima u vlasništvu dodatnu nekretninu. Samo 5,9\% ispitanika ima još jedan stan ili kuću osim onoga u kojem živi, a 5,3\% posjeduje i vikendicu. Ali zato brojni ispitanici $(58,2 \%)$ imaju $k$ klet $^{19}$, što je u tom kraju vrlo uobičajeno jer se najčešće radi o ruralnoj baštini koju su naslijedili od svojih predaka.

18 Prosječne mjesečne isplaćene neto plaće zaposlenih za prosinac 2012., Priopćenje 9.1.1/12., DZS, Zagreb, 2013.

19 Klet je pojam koji se u ovim krajevima koristi za kućicu u vinogradu (gorice) gdje se sprema vino i provodi slobodno vrijeme. Uglavnom je građena od prirodnih materijala (drva, blata, pljeve od pšenice, pruća i sl.). 
Pitanjem Može li ispitanik spojiti kraj s krajem? željelo se saznati kako ispitanici osobno procjenjuju svoje materijalno stanje. Većina procjenjuje da svojim prihodima teško može zadovoljiti sve potrebe svog kućanstva. Tako 17,6\% ispitanika navodi velike poteškoce u ostvarivanju svojih potreba, 34,7\% srednje i 33,5\% male. Manji dio ispitanika nema ekonomske teškoće, pa tako 8,8\% namiruje sve materijalne troškove kućanstva prilično lako, 1,8\% lako i 3,5\% vrlo lako.

Tablica 6.

Pokazatelji životnog standarda kućanstva

\begin{tabular}{|l|c|c|c|c|c|c|c|c|}
\hline & \multicolumn{2}{|c}{ Ukupno } & \multicolumn{3}{c}{ Da, mogu si } & \multicolumn{2}{c}{ Ne, ne mogu si } \\
& $\mathrm{N}$ & $\%$ & $\mathrm{~N}$ & $\%$ & $\mathrm{~N}$ & $\%$ & $\mathrm{~N}$ & $\%$ \\
\hline Održati ke kuću odgovarajuće toplom & 170 & 100,0 & 150 & 88,2 & 9 & 5,3 & 11 & 6,5 \\
\hline $\begin{array}{l}\text { Platiti jednotjedni godišnji odmor } \\
\text { izvan kuće }\end{array}$ & 170 & 100,0 & 65 & 38,2 & 82 & 48,2 & 23 & 13,5 \\
\hline Zamijeniti bilo koji istrošeni namještaj & 170 & 100,0 & 64 & 37,6 & 64 & 37,6 & 42 & 24,7 \\
\hline $\begin{array}{l}\text { Imati obrok s mesom ili ribom svaki } \\
\text { drugi dan ako želi }\end{array}$ & 170 & 100,0 & 147 & 86,5 & 12 & 7,1 & 11 & 6,5 \\
\hline Kupiti novu odjeću & 170 & 100,0 & 101 & 59,4 & 41 & 24,1 & 28 & 16,5 \\
\hline $\begin{array}{l}\text { Pozvati prijatelje ili obitelj na obrok/ } \\
\text { piće barem jedno mjesečno }\end{array}$ & 170 & 100,0 & 148 & 87,1 & 12 & 7,1 & 10 & 5,9 \\
\hline
\end{tabular}

Materijalno blagostanje kao objektivna kompozitna dimenzija (raznih pokazatelja vezanih uz materijalno stanje pojedinca) ukupne kvalitete života stanovnika općine Gornja Rijeka ispitano je pomoću šest pokazatelja životnog standarda kojima se koristio UNDP-a u istraživanju kvalitete života u Hrvatskoj 2006. godine (UNDP, 2007.). Od ispitanika se tražilo da odgovore mogu li si priuštiti ponuđene mogućnosti i/ili način ponašanja (tablica 6.). Dimenzija standarda stanovanja mjerila se dvama pokazateljima: mogućnošću zadovoljavajućeg grijanja kuće zimi i zamjenom dotrajalog namještaja. Od ukupno 170 ispitanika velika većina $(88,2 \%)$ izjavila je da bez problema mogu održati kuću odgovarajuće toplom, 5,3\% ispitanika nema tu mogućnost. Podjednak broj ispitanika, otprilike po trećina $(37,6 \%)$, može si i ne može priuštiti zamjenu bilo kojeg istrošenog namještaja kada poželi. Pojedinci koji nisu u mogućnosti zamijeniti namještaj bez većih problema izjavljuju: „radi se o dobru koje može potrajati“, „ne smeta nam ako je istrošen“, „nema potrebe za njegovom učestalom izmjenom jer se time stvara dodatan, nepotreban trošak" i sl.

Jedan od najzanimljivijih pokazatelja bilo je pitanje o kvaliteti prehrane, tj. imaju li materijalnu mogućnost jesti meso ili ribu svaki drugi dan, na što je jedan od ispitanika s osmijehom odgovorio: „kako ne, to je uvijek moguće, jadan seljak ako si to ne može priuštiti“. Naravno, pritom većina ispitanika koja si može $(86,5 \%)$ priuštiti obrok s mesom ili ribom svaki drugi dan, s obzirom na područje u kojem žive i stil prehrane, podrazumijeva obrok s mesom. U tom se dijelu Hrvatske riba uglavnom jede petkom, kada je nemrs ili pred velike vjerske blagdane, kada je post. 
Nešto više od polovice ispitanika $(59,4 \%)$ navodi da si može priuštiti kupnju nove odjeće, a među onih $24,1 \%$ koji nemaju tu mogućnost vrlo je često objašnjenje bilo da im je „važnije zadovoljiti osnovne životne potrebe“.

Odgovori o mogućnosti odlaska na plaćeni odmor od tjedan dana izvan kuće jednom godišnje pokazuju da to ne može gotovo polovica ispitanika (48,2\%). Svega nešto više od trećine ispitanika $(38,2 \%)$ ima dostatna financijska sredstva za jednotjedni godišnji odmor. Ponekad nemogućnost nije vezana isključivo uz nedostatna financijska sredstva, već problem predstavlja rad na poljoprivrednom gospodarstvu, koje iziskuje svakodnevnu prisutnost poljoprivrednika, a ispitanici nemaju kome prepustiti brigu za životinje i zemlju.

Na pitanje mogu li si priuštiti pozvati prijatelje/rodbinu na piće ili obrok jednom mjesečno dobiveno je najviše pozitivnih odgovora. Od ukupno 170 ispitanika njih 148 redovito održava kontakt s članovima obitelji i prijateljima, koji su nerijetko vezani uz zajednički obrok ili druženje uz piće.

Sastavni dio mjerenja pokazatelja materijalnog blagostanja bio je i dio pitanja usmjeren na temeljnu gospodarsku aktivnost vezanu uz pojam ruralnih prostora - poljoprivredu. Pogleda li se u ne tako daleku prošlost, Hrvatska je još 1953. bila agrarna zemlja, u kojoj je 56,4\% stanovništva u ukupnom bilo poljoprivredno. Međutim „[...] stav države o ulaganjima u poljoprivredu bitno je odredio tokove migracija radne snage i odnos prema selu" (Cifrić, 1987.:41). Istovremeno s demografskom regresijom primarno uzrokovanom masovnim iseljavanjem iz sela većinom prema gradovima, ali i inozemstvu, odvijaju se i velike promjene u vrstama djelatnosti na selu. Tradicionalne aktivnosti kao što su poljoprivreda, stočarstvo, šumarstvo, ribolov više nisu primarne i temeljne u gospodarstvu ruralnih područja.

Tako se 1960-ih i 1970-ih godina zapošljavanjem stanovnika iz ruralnih prostora u nepoljoprivrednim djelatnostima u gradu značajno mijenjao njihov način života i organizacija svakodnevnice. Zbog niskih plaća, jer je uglavnom bila riječ o slabije obrazovanim radnicima, mnogi od njih bili su prisiljeni nastaviti raditi i na poljoprivrednom imanju kako bi kroz vlastitu proizvodnju, tj. naturalni prihod poboljšali materijalni standard kućanstva, te su tako formirana tzv. mješovita kućanstva. Za razliku od tada, danas se dio kućanstava odlučuje za vlastitu proizvodnju hrane ne samo zbog oskudice već i zbog želje da jede kvalitetno i zdravo.

Koliko je poljoprivreda važna za današnji život hrvatskog sela? Analiza dobivenih odgovora ukazuje na još uvijek jaku povezanost života na selu i poljoprivrede. Čak u četiri petine kućanstava ispitanika barem se netko od članova bavi poljoprivredom. Tako je na pitanje Bavi li se netko od članova kućanstva poljoprivredom? $19,4 \%$ ispitanika odgovorilo da se svi u kućanstvu bave poljoprivredom, dok se u 61,2\% kućanstava samo neki članovi bave poljoprivredom. Poljoprivreda je i dalje bitan čimbenik u načinu života seoske zajednice, u načinu korištenju prostora, ali i u prihodima. Prihod od poljoprivrede bio je i dalje je važan u strategiji ekonomskog opstanka seoskih kućanstava, i to posebice onih s nižim prosječnim primanjima. 
Od 170 ispitanika u uzorku $53(31,2 \%)$ ne posjeduje poljoprivredno gospodarstvo. Poredano po udjelu ispitanika, polovina kućanstava $(50,4 \%)$ ima posjed veličine između 1,1 i 3 hektara, četvrtina (25,6\%) između 3,1 i 5 hektara, 7,7\% od 5,1 do 10 hektara, 6,8\% manje od 1 hektara, 5,1\% 10,1 do 20 hektara i samo 5 ispitanika $(4,3 \%)$ više od 20 hektara.

Uz udio ispitanika koji nemaju poljoprivredno gospodarstvo još 2,4\% ne radi u poljoprivredi. Ostali, njih 33,5\% svakodnevno radi poljoprivredne poslove na svojim imanjima, 23,5\% povremeno i još 10\% rijetko.

Obiteljsko poljoprivredno gospodarstvo (OPG) ima registrirano 100 ispitanika (58,8\% kućanstava), i od toga najveći broj od 1,1 do 3 ha (56 ispitanika), a još 28 ispitanika od 31,1 do 5 ha. Samo osam ispitanika (4,7\%) ima OPG koji je u sustavu PDV-a. I to isključivo oni s vlasništvom nad poljoprivrednom površinom od 10 do 20 ha (svega troje ispitanika) i s više od 20 ha (još četvero), što može biti pouzdan pokazatelj tržišnog bavljenja poljoprivredom. ${ }^{20}$

U Hrvatskoj je već desetljećima prisutan problem veličine posjeda, jer prevladavaju mali rasparcelirani posjedi na kojima je nemoguće organizirati ozbiljniju tržišnu proizvodnju. Krajem 1990-ih godina u agrarnoj strukturi Hrvatske jednu trećinu činila su gospodarstva do 1 hektara, drugu trećinu ona između 1 i 3 hektara i preostalu trećinu veća gospodarstva (Župančić, 2002.). I u trenutku ulaska Hrvatske u Europsku uniju situacija se nije bitno izmijenila. Polovinu ukupno obrađenog zemljišta i dalje čine površine malih poljoprivrednih gospodarstva. Prema podacima Agencije za plaćanje u poljoprivredi, ribarstvu i ruralnom razvoju ${ }^{21}$, početkom 2015. oko 60\% OPG-ova koristilo je do 3 hektara zemljišta, dok je samo 2,34\% posjeda bilo veće od 20 hektara. Stoga je nužno mjerama regionalnog razvoja provesti okrupnjivanje posjeda i katastarskih čestica zbog ekonomičnijeg iskorištavanja zemlje, ali i ulaganja u proizvodnju - od kupovine i iskorištavanja mehanizacije do proizvodnje količina proizvoda koje mogu biti dostatne za održivost pojedinog poljoprivrednog gospodarstva.

\section{Umjesto zaključka}

Kontinuiranom depopulacijom ruralnih područja Hrvatske, koju osnažuje nastavak iseljavanja iz sela ne samo prema hrvatskim gradovima već, s otvaranjem tržišta za radnike iz Hrvatske u zemljama Europske unije, u znatnom broju i prema inozemstvu, nastavlja se neravnomjeran razvoj Hrvatske na više razina: u rasporedu stanovništva, gospodarskom razvoju i korištenju prostora. Upravo tu transformaciju moguće je mjeriti posredno i neposredno istraživanjima kvalitete života stanovništva ruralnih prostora.

20 U sustav PDV-a poljoprivrednik može ući dobrovoljno ili obavezno kad je ostvario primitke veće od 85.000,00 kuna u jednoj poslovnoj godini.

21 Jutarnji list, 27. ožujka 2015., Zlatko Šimić „Nova komasacija“, str. 4 i 5. 
S obzirom na probleme koje ruralni prostor i stanovništvo proživljavaju zadnjih desetljeća u Hrvatskoj: zanemarivanje zemljišnih potencijala, pad poljoprivredne proizvodnje, pad vrijednosti zemljišta, pad životnog standarda stanovništva ruralnih prostora, starenje stanovništva, jedan od ciljeva ovoga rada bio je znanstvenim spoznajama skrenuti pozornost na probleme stanovništva hrvatskog ruralnog prostora te potaknuti nova istraživanja na čije bi se rezultate trebale oslanjati javne politike koje vode brigu o razvoju Hrvatske. Naime ne mogu se na jednak način tretirati problemi različitih ruralnih prostora jer ne postoji jedinstveno rješenje za sve ruralne regije.

Ispitanicima općine Gornja Rijeka na kraju upitnika postavljeno je pitanje Uzevši sve do sada navedene pojedinosti u obzir, kako procjenjujete vlastitu kvalitetu života? Odličnom ukupnu kvalitetu života ocjenjuje svega sedam ispitanika (4,1\%), a po 74 ispitanika (43,5\%) kvalitetu života ocijenilo je kao dobru i ni dobru ni lošu. Petnaest ispitanika ocijenilo je kvalitetu života lošom (5,3\%) i jako lošom (3,5\%). Pritom je varijabla koja se pokazala značajnom pri ukupnoj procjeni kvalitete života bila visina prosječnih mjesečnih primanja kućanstva. Ono što ispitanici, potvrdilo je i ovo istraživanje, najviše cijene u svojoj svakodnevnici i što pridonosi višoj kvaliteti života očuvane su društvene mreže i kvalitetni međuljudski odnosi, koji su izrazito važni u malim ruralnim zajednicama s ograničenim resursima i socijalnim kapitalom.

Porast kvalitete života ruralnog stanovništva pa tako i stanovništva općine Gornja Rijeka u velikoj mjeri ovisi o provedbi programa namijenjenih razvoju ruralnih područja Hrvatske. Primjerice jedan od prijedloga za demografsku obnovu opustošenih ruralnih područja potaknuti je „opstanak mladih u ruralnim područjima odnosno njihov povratak iz gradova, [za što je] nužno osigurati primjerene životne i radne uvjete [...] omogućiti mladima zapošljavanje i izvan poljoprivrednih zanimanja." (Program ruralnog razvoja RH za razdoblje 2014. - 2020., 2015.:12). Za rast životnog standarda, kao jednog od temeljnih uvjeta kvalitete života u ruralnim područjima, nužno je staviti što više zemljišta u funkciju, čime bi se povećala poljoprivredna proizvodnja, a posredno i razvili prerađivački kapaciteti i prateće industrije u prehrambenom sektoru (što bi također otvorilo nova radna mjesta). Daljnji razvoj komunalne infrastrukture ruralnih područja i rješenje okrupnjivanja posjeda uvjet je razvoja i samoodrživosti obiteljskih gospodarstava kao jednog od temelja materijalne sigurnosti stanovništva hrvatskih sela. Materijalno blagostanje, koje ovisi o otvaranju novih radnih mjesta i porastu zaposlenosti kao i ukupnih prihoda stanovništva razvojem i lokalnog poduzetništva, nije moguće bez poticanja pozitivne poduzetničke klime među mještanima, odnosno razvoja novih poslovnih aktivnosti na području općine. 


\section{Literatura}

1. Akrap, A. i Čipin, I. (2006). Socijalni sterilitet u Hrvatskoj-zašto smo neoženjeni $i$ neudane. Zagreb: Ministarstvo obitelji, branitelja i međugeneracijske solidarnosti.

2. Bengs, C. and Zonneveld, W. (2002). The European discourse on urban-rural relationships: A new policy and research agenda. Built Environment, 28 (4): 278-289.

3. Brereton, F.; Bullock C.; Clinch, J. P.; Scott, M. (2011). Rural change and individual well-being: the case of Ireland and rural quality of life. European Urban and Regional Studies, 18 (2): 203-227.

4. Brereton, F.; Clinch, J. P. and Ferreira, S. (2008). Happiness, geography and the environment. Ecological Economics, 65 (2): 386-396.

5. Brown, D. L. and Schafft, K. A. (2011). Rural People and Communities in the 21st Century: Resilience and Transformation. Cambridge: Polity.

6. Cifrić, I. (1987). Industrijalizacija i ruralne sredine. Sociologija sela, 95-98: 37-44.

7. Cummins, R. (1997). The Comprehensive Quality of Life Scale - Intellectual Disability, (ComQoL), Manual. Toorak: Deakin University School of Psychology.

8. Fahey, T.; Nolan, B. and Whelan, C. (2003). Monitoring quality of life in Europe. European Foundation for the Improvement of Living and Workin Confitions, Office for Official Publications and European Communities, Luxemburg.

9. Gabriel, Z. and Bowling, A. (2004). Quality of life from the perspectives of older people. Ageing E Society, 24 (5): 675-691.

10. Halfacree, K. (1996). Out of place in the country: Travellers and the „rural idyll“. Antipode, 28 (1): 42-71.

11. Hodžić, A. (1976). Inovacije u stanovanju i opremljenosti domaćinstava te orijentacija u potrošnji seoskog stanovništva. Sociologija sela, 53-54: 50-66.

12. Hodžić, A. (2000). Socijalna struktura i mobilnost seoskog stanovništva. Sociologija sela, 38 (1/2): 79-107.

13. Hodžić, A. (2002). Seoska svakodnevnica, U: Seferagić, D. (Ur.). Selo: izbor ili usud. Zagreb: IDIZ, 73-97.

14. Klempić Bogadi, S. i Podgorelec, S. (2009). Sociodemografske značajke i procesi u hrvatskim obalnim gradovima. Geoadria, 14 (2): 221-247.

15. Klempić Bogadi, S. i Podgorelec, S. (2011). Sociogeografske promjene u malim otočnim zajednicama - primjer otoka Zlarina, Geoadria, 16 (2): 189-209.

16. Klempić Bogadi, S., Podgorelec, S. i Šabijan, M. (2015). Hrvatsko selo na početku 21. stoljeća - studija slučaja općina Gornja Rijeka. Sociologija i prostor, 53 (2): 139-161.

17. Lay, V. (2002). Prilozi osmišljavanju usmjeravanja razvitka ruralnih prostora Hrvatske na osnovama ekološke i gospodarske održivosti, U: Rogić, I.; Štambuk, M. i Mišetić, A. (Ur.). Prostor iza. Kako modernizacija mijenja brvatsko selo. Zagreb: Institut društvenih znanosti „Ivo Pilar“, 289-304.

18. Lukić (2012). Mozaik izvan grada - tipologija ruralnih i urbaniziranih naselja Hrvatske. Samobor: Meridijani.

19. McCarthy, J. (2005). Rural geography: multi-functional rural gepgraphies - reactionary or radical?, Progress in Human Geography, 29 (6): 773-782. 
20. Megone, C. (1990). The Quality of Life - Starting from Aristotle, in: Baldwin, S.; Godfrey, C. and Propper, C. (Eds.). Quality of life - Perspectives and Policies. London: Routledge, 28-41.

21. Moreno, L. (2002). Mediterranean Welfare and 'Superwomen', Working Paper 02-02, Unidad de Políticas Comparadas, http://digital.csic.es/bitstream/10261/1496/1/dt-0202.pdf, (7.6.2012).

22. OECD (2006). The New Rural Paradigm - Policies and Governance. Paris: OECD.

23. Pacione, M. (2003). Urban environmental quality and human wellbeing - a social geographical perspective. Landscape and Urban Planning, 65 (1):19-30.

24. Podgorelec, S. i Klempić Bogadi, S. (2013). Gradovi potopili škoje - Promjene u malim otočnim zajednicama. Zagreb: Institut za migracije i narodnosti.

25. Program ruralnog razvoja $R H$ za razdoblje 2014.-2020. (2015). Zagreb: Ministarstvo, poljoprivrede, http://www.mps.hr/ipard/UserDocsImages/ Postpristupno\%20razdoblje\%20\%20EAFRD/PRR\%202014-2020\%20finalna\%20ina $\%$ C 4\%8Dica\%20HR/PRR\%20RH $\% 202014-2020$ v1.4 finalna $\% 20$ ina\%C4\%8Dica.pdf (15.12.2016).

26. Quality of Life in Europe, First European Quality of Life Survey 2003. (2004). The European Foundation for the Improvement of Living and Working Conditions, Ireland.

27. Seferagić, D. (1990). Razlike u stanovanju između grada i sela, U: Promjene u svakodnevnom životu sela i grada. Zagreb: IDIZ, 133-159.

28. Seferagić, D. (1993). Kvaliteta svakodnevnog življenja u prostoru. Prostor, 1 (24): 223-234.

29. Seferagić, D. (2000). Kvaliteta življenja u selu u tranziciji. Sociologija sela, 38 (1-2): 109-149.

30. Svirčić Gotovac, A. (2006). Kvaliteta stanovanja u mreži naselja Hrvatske. Sociologija sela, 44 (1): 105-126.

31. Štambuk, M. (1991). Društvene mijene ruralnog prostora Hrvatske. Sociologija sela, 111-114, 1-10.

32. UNDP (2007). Kvaliteta života u Hrvatskoj. Regionalne nejednakosti. Zagreb: UNDP u Hrvatskoj.

33. Župančić, M. (2002). Vitalni poljoprivrednici i drugi akteri u razvoju ruralnih područja, U: D. Seferagić (Ur.). Selo: izbor ili usud. Zagreb: IDIZ, 35-71.

34. Žutinić, Đ.; Kovačić, D.; Grgić, I.; Markovina, J. (2010). Percepcija kvalitete življenja i namjere o odlasku iz ruralnih sredina. Društvena istraživanja, 19 (12): 137-159.

\section{Izvori:}

Godišnji bruto domaći proizvod za 2014. (ESA 2010), Priopćenje 12.1.4., DZS, Zagreb, 2016.

Jutarnji list, 27. ožujka 2015., Zlatko Šimić „Nova komasacija“, str. 4 i 5.

Popis stanovništva, kućanstava i stanova 2011., DZS, Zagreb, www.dzs.hr i posebna obrada

Primjena informacijskih i komunikacijskih tehnologija (IKT) u kućanstvima i kod pojedinaca u 2015., prvi rezultati, Priopćenje 2.3.2., DZS, 2015. 
Prosječne mjesečne isplaćene neto plaće zaposlenih za prosinac 2012., Priopćenje 9.1.1/12., DZS, Zagreb, 2013.

Večernji list, Denis Derk „Samo 47 posto građana Hrvatske pročitalo barem jednu knjigu u posljednjih godinu dana - Više od prosjeka čita se u Zagrebu, Primorju i Dalmaciji. http://www.vecernji.hr/knjige/samo-47-posto-gradana-hrvatskeprocitalo-barem-jednu-knjigu-u-posljednjih-godinu-dana-1078522, (15.12.2016.) Zakonu o lokalnoj i područnoj (regionalnoj) samoupravi, Narodne novine 33/01, 60/01, 129/05, 109/07, 125/08, 36/09, 36/09, 150/11, 144/12, 19/13, 137/15.

Zakonu o područjima posebne državne skrbi, Narodne novine 86/08, 57/11, 51/13, 148/13, 76/14, 18/15. 


\title{
Sanja Klempić Bogadi
}

Institute for Migration and Ethnic Studies, Zagreb, Croatia

e-mail:sanja.klempic@imin.hr

\section{Sonja Podgorelec}

Institute for Migration and Ethnic Studies, Zagreb, Croatia

e-mail:sonja.podgorelec@imin.hr

\author{
Monika Šabijan \\ Dropkovec, Croatia \\ e-mail:monika.sabijan@gmail.com
}

\section{Material Well-Being - an Objective Dimension of the Rural Population Life Quality. The Municipality of Gornja Rijeka}

\begin{abstract}
The paper analyses further results* of the empirical research conducted in the settlements of the municipality of Gornja Rijeka. The aim of the research was to deepen knowledge about the conditions which determine the quality of life of the Croatian rural area population. According to the definition by R. Cummins (1991), material well-being is one of basic composite indicators of the overall quality of life. For the purpose of this paper, prosperity is measured by questions about the quality of housing, equipment of dwellings with elementary infrastructure and consumer durables, the material status (income) of households and the role of agriculture as a core economic sector in the total tangible image of rural households. A survey on a sample of 170 respondents aged 18 to 60, including an equal number of men and women, was conducted for the purpose of this study in 2012.
\end{abstract}

In the Croatian village of the 1960s, modernization of housing started with the building of municipal infrastructure, significant quality improvement in the construction of houses, increased living space and use of modern household appliances. In the settlements of Gornja Rijeka municipality, the size of living space, equipment of households with basic infrastructure and durable goods is satisfactory and can be compared with urban areas.

However, the material status of households in this municipality is not satisfactory because the total income in more than half of them is lower than the average Croatian salary. Most respondents estimate that their income can hardly meet the monthly needs of their households. Although agriculture is no longer the main source of income for rural population, it is still a relevant source of financial security, a determining factor in the entire life of rural communities, especially in the organization of everyday activities and use of space.

Key words: village, municipality of Gornja Rijeka, quality of life, dwelling, infrastructure, material status, agriculture.

* First results are presented in the paper Croatian village at the beginning of 21st century - case study of Gornja Rijeka municipality by Klempić Bogadi, S., Podgorelec, S., Šabijan, M. (2015), Sociology and Space, 53 (2): 139-161. 